\title{
Case Report: Diagnosis of hypogeusia after oral exposure to commercial cleaning agent and considerations for clinical
}

\section{taste testing [version 1; peer review: 1 approved, 1 approved with reservations, 1 not approved]}

\author{
Marie Jetté(i), Catherine Anderson, Vijay Ramakrishnan \\ Department of Otolaryngology, University of Colorado School of Medicine, Aurora, CO, 80045, USA
}

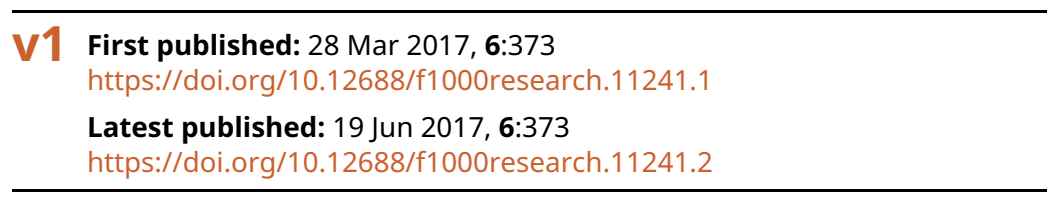

\section{Abstract}

Few reports in the literature document acute taste disturbance following exposure to toxic chemicals. We describe the case of a 54year-old man who presented with primary complaint of tongue numbness and persistent problems with taste 1.5 years following oral exposure to a commercial cleaning agent. A test of olfaction revealed normosmia for age and gender. Lingual tactile two-point discrimination testing showed reduced somatosensation. Taste threshold testing using a 3-drop method demonstrated severe hypogeusia, though the patient was able to discriminate tastants at lower concentrations with a whole mouth swish and spit test. We conclude that clinical evaluation of dysgeusia can be performed using a number of previously published testing methods, however, determining causative factors may be confounded by duration since exposure, lack of knowledge of baseline taste function, and medications. Although many testing options exist, basic taste testing can be performed with minimal expertise or specialized equipment, depending on the patient history and goals of evaluation.

\section{Keywords}

dysgeusia, hypogeusia, taste, tongue, burning mouth syndrome

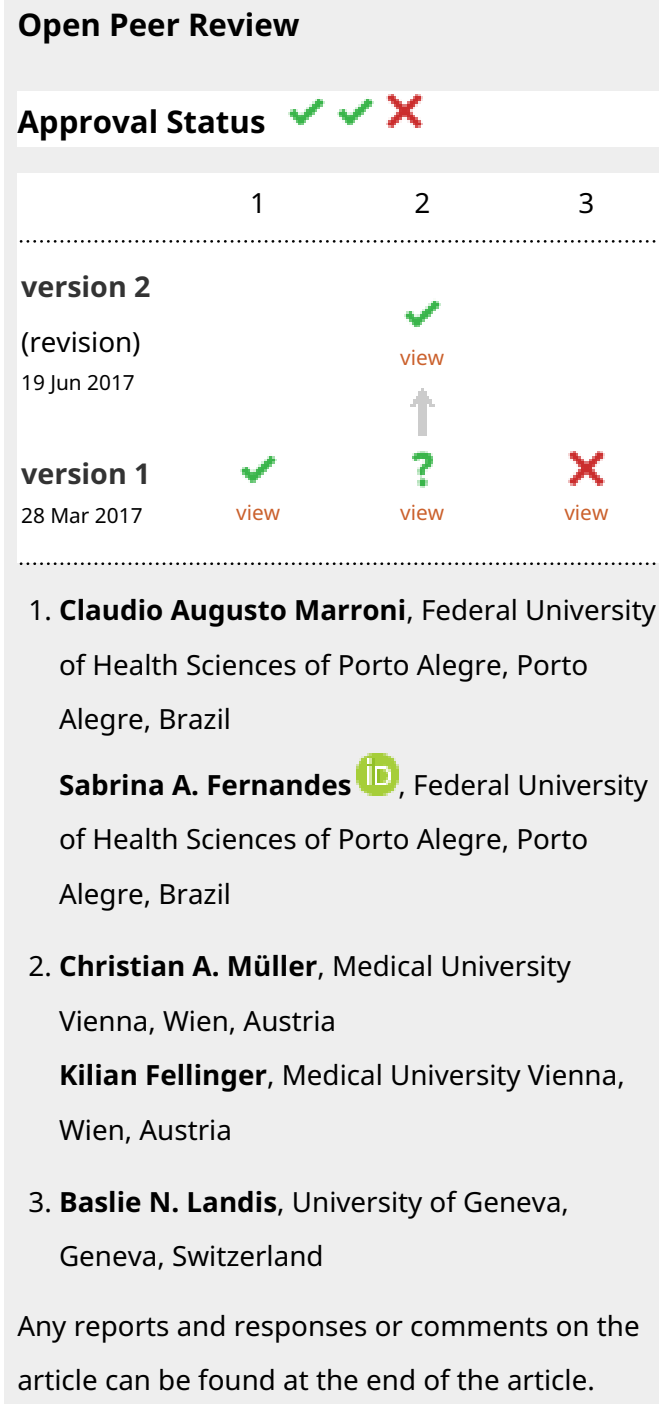

1. Claudio Augusto Marroni, Federal University of Health Sciences of Porto Alegre, Porto Alegre, Brazil

Sabrina A. Fernandes ID, Federal University of Health Sciences of Porto Alegre, Porto Alegre, Brazil

2. Christian A. Müller, Medical University Vienna, Wien, Austria

Kilian Fellinger, Medical University Vienna, Wien, Austria

3. Baslie N. Landis, University of Geneva, Geneva, Switzerland Any reports and responses or comments on the article can be found at the end of the article. 
Corresponding author: Vijay Ramakrishnan (vijay.ramakrishnan@ucdenver.edu)

Competing interests: No competing interests were disclosed.

Grant information: Research reported in this publication was supported by the National Institute on Deafness and Other Communication Disorders of the National Institutes of Health under award numbers K23DC014747 and T32DC012280.

The funders had no role in study design, data collection and analysis, decision to publish, or preparation of the manuscript.

Copyright: @ 2017 Jetté $\mathrm{M}$ et al. This is an open access article distributed under the terms of the Creative Commons Attribution License, which permits unrestricted use, distribution, and reproduction in any medium, provided the original work is properly cited. Data associated with the article are available under the terms of the Creative Commons Zero "No rights reserved" data waiver (CC0 1.0 Public domain dedication).

How to cite this article: Jetté M, Anderson C and Ramakrishnan V. Case Report: Diagnosis of hypogeusia after oral exposure to commercial cleaning agent and considerations for clinical taste testing [version 1; peer review: 1 approved, 1 approved with reservations, 1 not approved] F1000Research 2017, 6:373 https://doi.org/10.12688/f1000research.11241.1

First published: 28 Mar 2017, 6:373 https://doi.org/10.12688/f1000research.11241.1 


\section{Introduction}

Disordered taste, referred to as dysgeusia, can lead to dramatic changes in weight and reduce quality of life. Causes for dysgeusia are variable and include primary medical disorders ${ }^{1}$, medication side effects ${ }^{2}$, chemicals and toxins ${ }^{3}$, local disorders of the mouth ${ }^{4}$, insufficient production of saliva ${ }^{5}$, and gastroesophageal reflux disease. Here we describe a case of hypogeusia following oral contact with a commercial cleaning agent, and discuss diagnostic considerations in determining the nature and extent of taste dysfunction.

\section{Patient information}

A 54-year-old Caucasian man presented with complaints of a dull sensation of the tongue, describing that his "taste seems off," associated with numbness and occasional dry mouth. The patient reported that the taste disturbance began 1.5 years prior to presentation, immediately after accidental oral exposure to a cleaning agent, which he gargled with and immediately expectorated. At the time of injury he noted tongue numbness and throat irritation, and subsequently reported to the emergency department. There, examination of the oral cavity revealed no findings indicative of serious mucosal injury such as significant swelling, deep ulceration, or chemical burn. At an urgent dental visit one day following the incident, the patient reported tongue burning and tingling sensations, with increased tooth and gum sensitivity, and the dentist's examination noted superficial irritation on the tongue and cheeks along with pharyngeal erythema. The patient was seen by an otolaryngologist approximately 3 weeks following the incident for complaints of burning and soreness of the tongue and loss of taste. His physical exam was notable for an area of mild erythema of the right lateral tongue, tender to palpation but without ulceration, and he was prescribed a supersaturated calcium phosphate rinse for oral mucositis and topical benzocaine for symptomatic relief. Approximately 6 weeks following the incident, the patient was seen in follow-up by the otolaryngologist for tongue soreness. At that time, examination revealed erythema and shallow erosion/ulceration of the dorsal tongue just anterior to the foramen cecum, and light erythema of the lateral tongue. The patient was diagnosed with candidiasis and prescribed nystatin. A follow-up appointment approximately 9 weeks after the incident showed resolution of physical exam findings, however, he continued to have symptoms.

The patient presented to our department 1.5 years after the injury, for evaluation of persistent subtotal loss of tongue sensation, both taste and somatosensation. During this visit, a complete head and neck examination was performed and was essentially normal, specifically with normal ear examination and intact cranial nerve exam. Intraoral examination demonstrated normal mucosa with no evidence of erythema or ulceration (Figures 1C, $1 \mathrm{E}, 1 \mathrm{~F})$. A shallow fissure was noted along the medial surface of the tongue (Figures 1A, 1D). An atrophic patch was noted on the posterior right tongue (Figure 1B), possibly consistent with geographic tongue. The patient's medical history was significant for
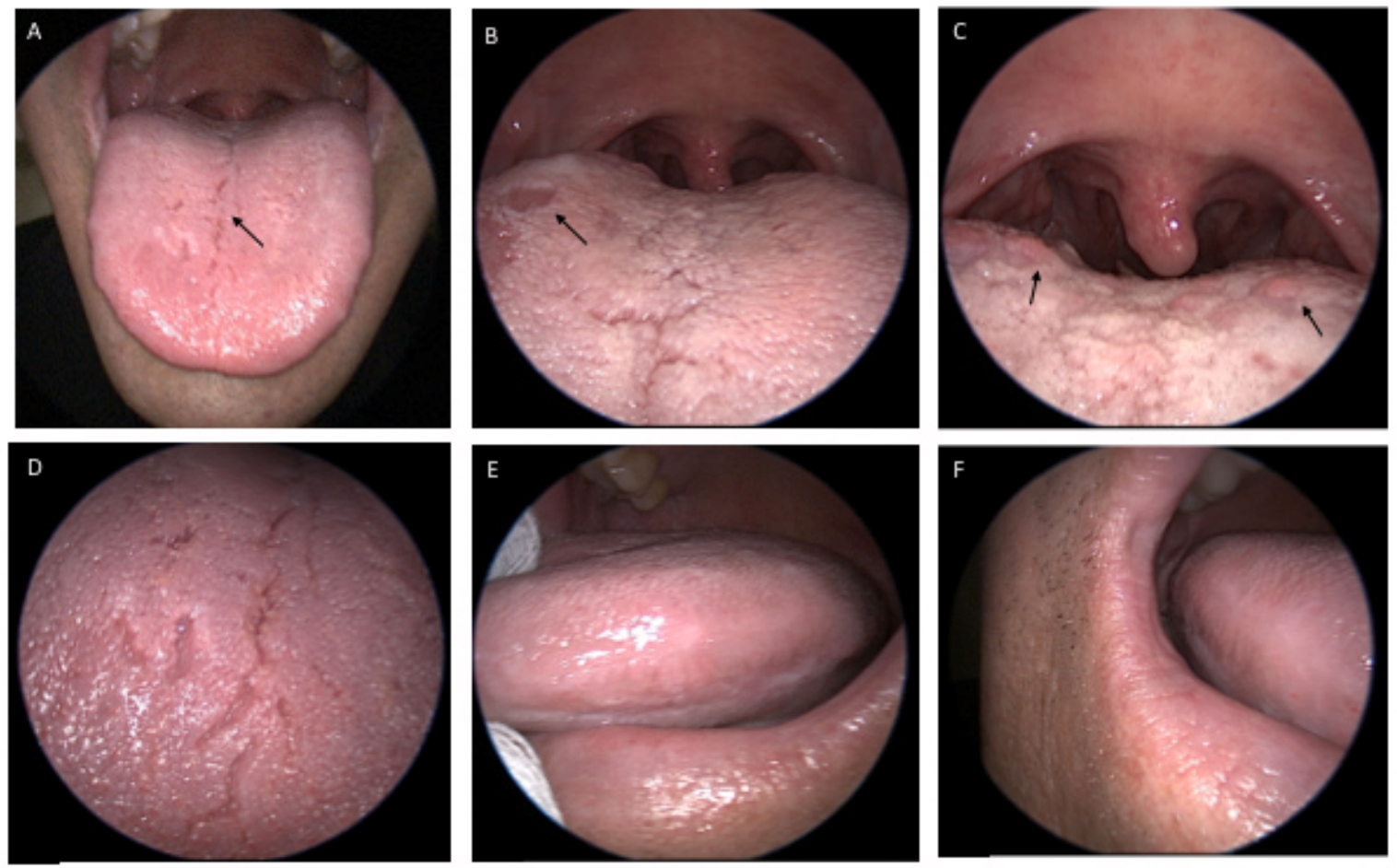

Figure 1. Images of patient's tongue taken 1.5 years following oral exposure to toxic cleaning agent. The oral mucosa appears normal, though there is some evidence of possible geographic tongue. Panels 1A and 1D show a slight fissure (arrow). Panel 1B demonstrates an atrophic patch (arrow) consistent with possible geographic tongue. The circumvallate papillae are intact as demonstrated in 1C (arrows). The lateral lingual mucosa appears normal (1E, 1F). 
hypertension and his surgical history was unremarkable. His body mass index was 25.8. Medications at the time of our evaluation included aspirin $81 \mathrm{mg}$, lisinopril, naproxen, and various vitamins and supplements including zinc.

A series of tests was assembled and administered to determine the nature and extent of the patient's dysgeusia, including: twocup forced choice test, two-point tactile discrimination, trigeminal nerve testing, three-drop taste threshold testing, and swish and spit whole mouth taste testing (Table 1).

\section{Diagnostic assessment}

\section{Smell testing}

Given that much of a patient's subjective perception of "taste" usually involves a contribution of odor via the olfactory system ${ }^{6}$ screening of olfactory function is generally performed in a taste evaluation. The extent to which this patient's dysgeusia was influenced by smell was assessed using the Smell Identification Test (SIT; Sensonics International, Haddon Heights, N.J.). The patient scored 34/40 correct responses on this test, putting him in the 33rd percentile for age and gender, categorized as normosmia ${ }^{7}$. This finding indicates that disordered smell is not a contributing factor in this patient's dysgeusia.

\section{Two-point tactile discrimination}

Two-point discrimination is a common neurological test of somatosensory function, and here it was utilized to assess the tongue. Calipers were used to present either one or two tactile stimuli to the tongue and the patient was asked to indicate if he felt one point or two. An ascending threshold was established by beginning with the detection points at $2 \mathrm{~mm}$ and gradually moving them apart until the patient perceived two distinct points. This was completed in each of four quadrants of the tongue including left posterior, right posterior,

Table 1. Taste test battery used to assess patient.

\begin{tabular}{|c|c|c|c|}
\hline Test & Objective & Supplies & $\begin{array}{c}\text { Completion } \\
\text { time }\end{array}$ \\
\hline $\begin{array}{c}\text { Smell } \\
\text { Identification } \\
\text { Test (SIT) }\end{array}$ & $\begin{array}{l}\text { Olfactory } \\
\text { function }\end{array}$ & $\begin{array}{c}\text { Commercial } \\
\text { test book }\end{array}$ & $10-15 \min$ \\
\hline $\begin{array}{c}\text { Two-Point } \\
\text { Tactile } \\
\text { Discrimination }\end{array}$ & $\begin{array}{l}\text { Somatosensory } \\
\text { function }\end{array}$ & Calipers & $5 \mathrm{~min}$ \\
\hline $\begin{array}{l}\text { Trigeminal } \\
\text { Nerve Testing }\end{array}$ & $\begin{array}{l}\text { Trigeminal } \\
\text { nerve function }\end{array}$ & $\begin{array}{l}\text { Spicy stimuli: } \\
\text { mustard, } \\
\text { wasabi, } \\
\text { capsaicin }\end{array}$ & $1 \mathrm{~min}$ \\
\hline $\begin{array}{c}\text { Forced Choice } \\
\text { Taste Test }\end{array}$ & $\begin{array}{c}\text { Detect } \\
\text { malingering }\end{array}$ & $\begin{array}{c}\text { Distilled } \\
\text { water Tastant } \\
\text { solutions } \\
\text { (see Table II) } \\
\text { Medicine cups }\end{array}$ & $5 \mathrm{~min}$ \\
\hline $\begin{array}{c}\text { Three- } \\
\text { Drop Taste } \\
\text { Threshold Test }\end{array}$ & $\begin{array}{l}\text { Gustatory } \\
\text { function }\end{array}$ & $\begin{array}{l}\text { Distilled } \\
\text { water Tastant } \\
\text { solutions } \\
\text { (see Table II) } \\
\text { Droppers }\end{array}$ & 20-30 min \\
\hline
\end{tabular}

left anterior, and right anterior until the two-point detection threshold was reached. Two-point detection thresholds were as follows:

- $\quad$ left posterior $=>23 \mathrm{~mm}$,

- $\quad$ right posterior $=22 \mathrm{~mm}$,

- $\quad$ left anterior $=18 \mathrm{~mm}$,

- $\quad$ right anterior $=16 \mathrm{~mm}$.

These thresholds were notably elevated relative to published means of $1.09 \mathrm{~mm}$ in the anterior region, $2.64 \mathrm{~mm}$ in the canine region, and $8.08 \mathrm{~mm}$ in the posterior region ${ }^{8}$.

\section{Trigeminal nerve testing}

Many chemicals that stimulate taste buds also stimulate trigeminal neurons when presented at high concentrations ${ }^{9}$. Conversely, compounds such as capsaicin and mustard oil elicit responses from trigeminal fibers but not from taste cells. Therefore, to test trigeminal involvement in the patient's dysgeusia, small boluses of mustard and chili pepper sauce were presented across the dorsal surface of the tongue using a cotton tip applicator and the patient was asked to describe his perception of each. The patient was able to detect both stimuli, describing the mustard as "sour" and guessing correctly that it was mustard, and describing the chili pepper sauce as "hot" and "spicy". These results indicate that trigeminal responses detected by nociceptive nerve fibers of the tongue were intact.

\section{Forced choice test}

To distinguish ageusia from malingering, the patient was presented with 6 trials of a forced choice task, whereby the patient was asked to swish $10 \mathrm{ml}$ of a detectable tastant concentration (the highest concentrations of sucrose and sodium chloride as outlined in Table 2) or its diluent (distilled water) and determine which contained the tastant. Sweet taste (i.e. detection of sucrose) is considered the most robust across the lifespan, and coincidentally this tastant is readily available ${ }^{10}$. In $6 / 6$ trials, the patient correctly indicated the cup containing the tastant. If the subject was truly ageusic and guessing at random, they would guess the correct cup $50 \%$ of the time, whereas scores deviating from 50 percent in either direction would indicate nonchance-level performance, and suggest that

Table 2. Tastant concentrations used for taste threshold testing. $1=$ mild, $2=$ mild-moderate, $3=$ moderate-strong, $4=$ strong. $\mathrm{g} / \mathrm{ml}$ indicates grams of dry tastant per milliliter of distilled water, and $\mathrm{M}$ indicates molarity.

\begin{tabular}{|c|c|c|c|c|}
\hline & Sweet & Salty & Sour & Bitter \\
\hline & Sucrose & Sodium chloride & Citric acid & Quinine $\mathrm{HCl}$ \\
\hline 1 & $\begin{array}{l}0.05 \mathrm{~g} / \mathrm{ml} \\
(0.15 \mathrm{M})\end{array}$ & $\begin{array}{c}0.016 \mathrm{~g} / \mathrm{ml} \\
(0.27 \mathrm{M})\end{array}$ & $\begin{array}{c}0.0125 \mathrm{~g} / \mathrm{ml} \\
(0.07 \mathrm{M})\end{array}$ & $\begin{array}{l}0.0001 \mathrm{~g} / \mathrm{ml} \\
(0.00025 \mathrm{M})\end{array}$ \\
\hline 2 & $\begin{array}{l}0.1 \mathrm{~g} / \mathrm{ml} \\
(0.29 \mathrm{M})\end{array}$ & $\begin{array}{l}0.04 \mathrm{~g} / \mathrm{ml} \\
(0.68 \mathrm{M})\end{array}$ & $\begin{array}{c}0.0225 \mathrm{~g} / \mathrm{ml} \\
(0.12 \mathrm{M})\end{array}$ & $\begin{array}{c}0.0002 \mathrm{~g} / \mathrm{ml} \\
(0.0005 \mathrm{M})\end{array}$ \\
\hline 3 & $\begin{array}{l}0.2 \mathrm{~g} / \mathrm{ml} \\
(0.58 \mathrm{M})\end{array}$ & $\begin{array}{l}0.1 \mathrm{~g} / \mathrm{ml} \\
(1.71 \mathrm{M})\end{array}$ & $\begin{array}{c}0.041 \mathrm{~g} / \mathrm{ml} \\
(0.21 \mathrm{M})\end{array}$ & $\begin{array}{c}0.0006 \mathrm{~g} / \mathrm{ml} \\
(0.0015 \mathrm{M})\end{array}$ \\
\hline 4 & $\begin{array}{l}0.4 \mathrm{~g} / \mathrm{ml} \\
(1.17 \mathrm{M})\end{array}$ & $\begin{array}{l}0.25 \mathrm{~g} / \mathrm{ml} \\
(4.28 \mathrm{M})\end{array}$ & $\begin{array}{c}0.075 \mathrm{~g} / \mathrm{ml} \\
(0.39 \mathrm{M})\end{array}$ & $\begin{array}{c}0.0015 \mathrm{~g} / \mathrm{ml} \\
(0.0038 \mathrm{M})\end{array}$ \\
\hline
\end{tabular}


the test taker knew the correct answer but purposely selected the wrong one. ${ }^{11}$ This quick test can be performed six times in a row if malingering is suspected, as there is only a 1 in 64 chance that an ageusic subject would guess incorrectly six times in a row.

Three-drop taste threshold test. A forced choice taste test $\mathrm{t}^{12,13}$ was used to determine detection thresholds of four tastants including sucrose (sweet), sodium chloride (salty), citric acid (sour) and quinine hydrochloride (bitter), with concentrations shown in Table 2. Each trial consisted of 3 stimuli presented in a pseudorandom order at room temperature; one stimulus was the tastant and the other two were diluent (distilled water). To present the stimuli, a single drop of liquid was squeezed from a $3 \mathrm{ml}$ plastic transfer pipette onto the center of the tongue dorsum, approximately $1.5 \mathrm{~cm}$ from the tip. The patient was asked to close his mouth following each drop and indicate which drop (the first, second, or third) had the tastant. Testing began with the highest (4) concentration of each stimulus and, if detected, proceeded with the next lower (3) concentration. If the next lower (3) concentration was not detected, the highest (4) concentration was presented in the following trial, and this cycle was repeated until there were 3 consecutive detections of a given concentration. Between each trial, the patient rinsed his mouth with tap water.

The patient was unable to detect the highest concentration of sucrose, indicating that his threshold for sweet detection is greater than $0.4 \mathrm{~g} / \mathrm{ml}(1.17 \mathrm{M})$. Salty, bitter, and sour stimuli were consistently detected at the highest (4) concentrations only. A follow up swish and spit forced-choice test comparing the lowest (1) concentrations of sour and sweet tastants to distilled water was administered to determine if whole mouth discrimination, where posterior as well as anterior taste buds can detect the tastant, would be different from single drop discrimination. The patient immediately discriminated both low concentration solutions and correctly identified the sweet stimulus as "mildly sweet" and the sour stimulus as "sour". These findings suggest that the patient's hypogeusia is more severe in the region of the anterior tongue where taste buds are more exposed.

\section{Discussion}

Taste buds in the anterior tongue are superficial receptor end organs, making them susceptible to direct chemical injury; however, reports of toxin-induced dysgeusia in the literature are rare even in surveys of specialty clinics. Smith et al. ${ }^{3}$ described a patient with severe hypogeusia after oral contact with ammonia that resulted in a chemical burn. Workers exposed to hydrocarbons have reported subjective disturbances in taste ${ }^{14}$, and taste thresholds are elevated in workers exposed to dichromate, chromic acid, and zinc chromate ${ }^{15}$. In our patient, a bathroom cleaner containing a proprietary organic salt made contact with the oral mucosa; based on comparison to similar cleaning materials, the presumed compound was likely urea sulfate, a mildly corrosive salt that rapidly breaks down into urea and sulfuric acid.

There are multiple potential reasons for the paucity of reported cases of chemical-induced taste dysfunction cases. First, clinical assessment of taste is not as standardized a practice as testing other senses like hearing and smell is; therefore, patients may not be objectively evaluated to determine the degree of taste dysfunction until several months or years have passed since the initial exposure. This obscures identification of a particular chemical or toxin as the causative agent. Further, taste cells are continually renewed ${ }^{16}$, so a superficial mucosal injury will likely resolve over time as damaged cells are replaced. Finally, several factors known to be associated with dysgeusia may confound determination of cause and effect, including various medications ${ }^{5}$, comorbid conditions like oral candidiasis ${ }^{4}$, diabetes ${ }^{5}$, hypothyroidism ${ }^{5}$, Sjogren's syndrome $^{17}$, and age ${ }^{18}$.

The constellation of symptoms and signs reported by the patient in this case may also be consistent with some features associated with burning mouth syndrome (BMS). BMS affects the oral mucosa, lips and/or tongue and is characterized by the sensation of burning, tingling, or numbness in the absence of visible inflammation or lesions ${ }^{19}$. BMS has been associated with two factors detailed in this report: angiotensin converting enzyme (ACE) inhibitors ${ }^{19}$ and oral candidiasis ${ }^{19}$. ACE inhibitors inhibit zinc action in the salivary glands and taste receptor cells thereby reducing saliva production and affecting taste ${ }^{20}$. Brown et al. ${ }^{21}$ described two cases of BMS associated with ACE inhibitors that subsequently improved after changes in drug therapy. Oral candidiasis caused by Candida albicans is a common fungal infection and estimates indicate that anywhere from $36-60 \%{ }^{22,23}$ of the population are carriers without clinical symptoms. Sakashita et al. ${ }^{24}$, reported that $70 \%$ of Candida carriers in their 50's demonstrated dysgeusia. The patient presented herein was treated for suspected (although unconfirmed) oral candidiasis approximately 6 weeks following reported onset of taste loss, suggesting that he may be a carrier for Candida albicans.

Thoroughly investigating the cause of a patient's dysgeusia allows the clinician to offer potential treatment options, but it is equally important to document and determine the extent of the taste disturbance in order to track a patient's recovery over time. Quantitative taste testing is relatively easy to perform in the clinic and should be used to assess taste function of patients complaining of both acute and chronic alterations in taste. Subjective patient reports may exaggerate or minimize the nature and extent of dysgeusia, and testing can determine whether the degree of dysfunction is normal relative to age. This information can be used for patient counseling, and may also be helpful to evaluate longitudinal improvement in an objective fashion. It is also possible to detect malingering by administration of simple, forced-choice tests.

Given the chronic nature of the patient's hypogeusia, we expect that it is unlikely that he will experience spontaneous resolution at this time point. If his taste dysfunction was truly a direct result of chemical injury to the oral cavity mucosa, the gustatory system exhibits a robust regeneraitve capacity, with taste cell renewal every $10-14$ days (see Barlow, $2015^{16}$ for a review). This suggests that function should have recovered within months of the incident. Medical treatment options that could be attempted include discontinuing lisinopril and trialing a different (nonsulfhydryl) ACE inhibitor ${ }^{20}$, or dietary supplementation with selenium methionine ${ }^{25}$.

We employed multiple tests targeting somatosensory function, trigeminal nerve response, taste thresholds for sweet, sour, bitter, and salty, and odor detection. There are additional 
tests reported in the literature that can also be used for measuring dysgeusia, some of which are commercially available. These include electrogustometry ${ }^{26}$ (e.g., TR-06 Rion Electrogustometer, Sensonics, Inc.), Taste Strips (Burghart), filter paper discs ${ }^{27}$, taste tablets $^{28}$, and subjective health-related quality-of-life questionnaires. For a standardized taste intensity testing protocol, clinicians may opt to follow the technical manual and scoring and interpretation guidelines included in the National Institutes of Health (NIH) Toolbox, as established by the National Health and Nutrition Examination Survey (NHANES) ${ }^{29}$. As a very basic measure, it is also possible to create testing solutions from storebought sugar (low concentration=3 tsp; high concentration=24 tsp) and salt (low concentration $=2$ tsp; high concentration $=14$ tsp) dissolved in $8 \mathrm{oz}(237 \mathrm{ml})$ distilled water to perform both tongue tip and whole mouth testing.

\section{Conclusion}

This case report adds to the limited literature on toxin-induced hypogeusia following oral exposure. We promote the concept that taste testing is relatively easy to perform and should be completed as soon as possible following an incident in order to determine the extent of injury and track improvement in function over time.

\section{Consent}

Written informed consent for publication of their clinical details and clinical images was obtained from the patient.
Author contributions

All authors designed the diagnostic battery. VRR administered the testing. MJ prepared the manuscript. All authors were involved in the revision of the draft manuscript and have agreed to the final content.

\section{Competing interests}

No competing interests were disclosed.

\section{Grant information}

Research reported in this publication was supported by the National Institute on Deafness and Other Communication Disorders of the National Institutes of Health under award numbers K23DC014747 and T32DC012280.

The funders had no role in study design, data collection and analysis, decision to publish, or preparation of the manuscript.

\section{Acknowledgements}

We acknowledge Sue Kinnamon, $\mathrm{PhD}$ and Tom Finger, $\mathrm{PhD}$, of the Rocky Mountain Taste and Smell Center, as well as members of the Kinnamon Lab including Aurelie Vandenbeuch, $\mathrm{PhD}$, Eric Larson, $\mathrm{PhD}$, Courtney Wilson, and Kyndal Davis for thoughtful commentary on this case.
1. Heckmann JG, Lang CJ: Neurological causes of taste disorders. In: Hummel, T, Welge-Lüssen A, eds. Taste and Smell: An Update. Basel: Karger; Adv Otorhinolaryngol. 2006; 63: 255-264. PubMed Abstract | Publisher Full Text

2. Fetting JH, Wilcox PM, Sheidler VR, et al.: Tastes associated with parenteral chemotherapy for breast cancer. Cancer Treat Rep. 1985; 69(11): 1249-1251. PubMed Abstract

3. Smith WM, Davidson TM, Murphy C: Toxin-induced chemosensory dysfunction: a case series and review. Am J Rhinol Allergy. 2009; 23(6): 578-581. PubMed Abstract | Publisher Full Text | Free Full Text

4. Grushka M, Ching V, Epstein J: Burning mouth syndrome. In: Hummel, T, WelgeLussen A, eds. Taste and Smell: An Update. Basel: Karger; Adv Otorhinolaryngol. 2006; 63: 278-287. PubMed Abstract | Publisher Full Text

5. Reiter ER, DiNardo LJ, Costanzo RM: Toxic effects on gustatory function. In: Hummel T, Welge-Lussen A, eds. Taste and Smell: An Update. Basel: Karger; Adv Otorhinolaryngol. 2006; 63: 265-277. PubMed Abstract | Publisher Full Text

6. Sumner D: Post-traumatic ageusia. Brain. 1967; 90(1): 187-202. PubMed Abstract | Publisher Full Text

7. Doty RL, Shaman P, Kimmelman CP, et al:: University of Pennsylvania Smell Identification Test: a rapid quantitative olfactory function test for the clinic. Laryngoscope. 1984; 94(2 Pt 1): 176-178. PubMed Abstract | Publisher Full Text

8. Minato A, Ono T, Miyamoto JJ, et al:: Preferred chewing side-dependent two-point discrimination and cortical activation pattern of tactile tongue sensation. Behav Brain Res. 2009; 203(1): 118-126. PubMed Abstract | Publisher Full Text

9. Simon SA, Wang Y: Chemical Responses of Lingual Nerves and Lingual Epithelia. In: Mechanisms of Taste Transduction. Ann Arbor, MI: CRC Press, Inc.; 2003; 225-252. Reference Source
10. Yamauchi Y, Endo S, Yoshimura I: A new whole-mouth gustatory test procedure. II. Effects of aging, gender and smoking. Acta Otolaryngol Suppl. 2002; (546): 49-59.

PubMed Abstract | Publisher Full Text

11. Greve KW, Bianchini KJ, Ameduri CJ: Use of a forced-choice test of tactile discrimination in the evaluation of functional sensory loss: a report of 3 cases. Arch Phys Med Rehabil. 2003; 84(8): 1233-1236. PubMed Abstract | Publisher Full Text

12. Henkin RI, Gill JR, Bartter FC: Studies on Taste Thresholds in Normal Man and in Patients with Adrenal Cortical Insufficiency: The Role of Adrenal Cortical Steroids and of Serum Sodium Concentration. J Clin Invest. 1963; 42(5): 727-735.

PubMed Abstract | Publisher Full Text | Free Full Text

13. Mueller C, Kallert S, Renner B, et al:: Quantitative assessment of gustatory function in a clinical context using impregnated "taste strips". Rhinology. 2003; 41(1): 2-6. PubMed Abstract

14. Hotz P, Tschopp A, Söderström D, et al:: Smell or taste disturbances, neurological symptoms, and hydrocarbon exposure. Int Arch Occup Environ Health. 1992; 63(8): 525-530. PubMed Abstract | Publisher Full Text

15. Seeber H, Fikentscher R: [Taste disorders in chromium exposed workers]. Z Gesamte Hyg. 1990; 36(1): 33-34. PubMed Abstract

16. Barlow LA: Progress and renewal in gustation: new insights into taste bud development. Development. 2015; 142(21): 3620-3629. PubMed Abstract | Publisher Full Text | Free Full Text

17. Henkin RI, Talal N, Larson AL, et al.: Abnormalities of taste and smell in Sjogren's syndrome. Ann Intern Med. 1972; 76(3): 375-383. PubMed Abstract | Publisher Full Text

18. Plattig KH, Kobal G, Thumfart W: [The chemical senses of smell and taste in the course of life - changes of smell and taste perception]. Z Gerontol. 1980; 13(2): 
149-157.

PubMed Abstract

19. Grushka M, Epstein JB, Gorsky M: Burning mouth syndrome. Am Fam Physician. 2002; 65(4): 615-620.

PubMed Abstract

20. Ackerman $\mathrm{BH}$, Kasbekar N: Disturbances of taste and smell induced by drugs. Pharmacotherapy. 1997; 17(3): 482-496. PubMed Abstract

21. Brown RS, Krakow AM, Douglas T, et al:: "Scalded mouth syndrome" caused by angiotensin converting enzyme inhibitors: two case report. Oral Surg Oral Med Oral Pathol Oral Radiol Endod. 1997; 83(6): 665-667.

PubMed Abstract | Publisher Full Text

22. Wright BA, Fenwick F: Candidiasis and atrophic tongue lesions. Oral Surg Oral Med Oral Pathol. 1981; 51(1): 55-61. PubMed Abstract | Publisher Full Text

23. Fotos PG, Vincent SD, Hellstein JW: Oral candidosis. Clinical, historical, and therapeutic features of 100 cases. Oral Surg Oral Med Oral Pathol. 1992; 74(1): 41-49.

PubMed Abstract | Publisher Full Tex

24. Sakashita S, Takayama K, Nishioka K, et al.: Taste disorders in healthy "carriers" and "non-carriers" of Candida albicans and in patients with candidosis of the tongue. J Dermatol. 2004; 31(11): 890-897.

PubMed Abstract | Publisher Full Text

25. Zazgornik J, Kaiser W, Biesenbach G: Captopril-induced dysgeusia. Lancet. 1993; 341(8859): 1542

PubMed Abstract | Publisher Full Text

26. Stillman JA, Morton RP, Hay KD, et al: Electrogustometry: strengths, weaknesses, and clinical evidence of stimulus boundaries. Clin Otolaryngol Allied Sci. 2003; 28(5): 406-410.

PubMed Abstract | Publisher Full Text

27. Sato $\mathrm{K}$, Endo $\mathrm{S}$, Tomita $\mathrm{H}$ : Sensitivity of three loci on the tongue and soft palate to four basic tastes in smokers and non-smokers. Acta Otolaryngol Suppl. 2002; (546): 74-82.

PubMed Abstract | Publisher Full Tex

28. Ahne G, Erras A, Hummel T, et al:: Assessment of gustatory function by means of tasting tablets. Laryngoscope. 2000; 110(8): 1396-1401.

PubMed Abstract | Publisher Full Text

29. Taste and Smell Examination Component Manual. National Health and Nutrition Examination Survey. 2013; Accessed August 1, 2016.

Reference Source 


\section{Open Peer Review}

\section{Current Peer Review Status: $\checkmark$ ? $\mathrm{X}$}

\section{Version 1}

Reviewer Report 31 May 2017

https://doi.org/10.5256/f1000research.12128.r22193

(c) 2017 Landis B. This is an open access peer review report distributed under the terms of the Creative Commons Attribution License, which permits unrestricted use, distribution, and reproduction in any medium, provided the original work is properly cited.

\section{Baslie N. Landis}

Department of Otorhinolaryngology, Head and Neck Surgery, Geneva University Hospitals, Medical School, University of Geneva, Geneva, Switzerland

\section{General Comments:}

The authors present a case of a patient who has accidentally ingested a cleaning agent and has long lasting oral taste and sensitivity problems.

\section{Major Comments:}

Although interesting, this case does not add much to the understanding of the underling mechanism.

We do not learn what the composition of the cleaning agent was.

The pictures are not really pathological. Tongues are like faces, they have a wide variety of individual differences which are not always pathological. The images suggest that the complaint and the neural damage can be seen. I do not think that if you would give these pictures to 5 ENT specialists without any history they would label them as pathological (unlike a clinical image where no text is needed and everybody knows the diagnosis).

Finally, the authors mix two things that do not fit together. There is an average case report and a general overview about taste testing. I think this is a kind of not suitable mix. The overview is too short and superficial and not critically discussed. The case report is not well discussed (as the discussion is about taste tests and not about the case). There is no further lab tests done for the case to rule out other diseases (Vitamin deficiencies, Sjögren, metabolic disorders, etc..). 1.5 year follow up is short for taste disorders. Recovery of severe dysgeusia takes up to 2 years (see reference [1])

\section{References}

1. Heiser C, Landis BN, Giger R, Cao Van H, et al.: Taste disorders after tonsillectomy: a long-term 
follow-up.Laryngoscope. 2012; 122 (6): 1265-6 PubMed Abstract | Publisher Full Text

Is the background of the case's history and progression described in sufficient detail? No

Are enough details provided of any physical examination and diagnostic tests, treatment given and outcomes?

No

Is sufficient discussion included of the importance of the findings and their relevance to future understanding of disease processes, diagnosis or treatment?

No

Is the case presented with sufficient detail to be useful for other practitioners?

No

Competing Interests: No competing interests were disclosed.

Reviewer Expertise: Clinical smell and taste disorders

I confirm that I have read this submission and believe that I have an appropriate level of expertise to state that I do not consider it to be of an acceptable scientific standard, for reasons outlined above.

Reviewer Report 30 May 2017

\section{https://doi.org/10.5256/f1000research.12128.r22595}

(C) 2017 Müller C et al. This is an open access peer review report distributed under the terms of the Creative Commons Attribution License, which permits unrestricted use, distribution, and reproduction in any medium, provided the original work is properly cited.

Christian A. Müller

Department of Otorhinolaryngology, Head and Neck Surgery, Medical University Vienna, Wien, Austria

Kilian Fellinger

Department of Otorhinolaryngology, Head and Neck Surgery, Medical University Vienna, Wien, Austria

First, we would like to thank the authors that they have illustrated the clinical importance of taste disorders and related diagnostic procedures based on this interesting case report.

Thorough medical history and validated assessment of sensory acuity is mandatory during the management of patients with smell and taste disorders. Consequently, we would like to suggest some revisions to the case report.

Although important causes of taste disorders are mentioned, some other causes, e.g., surgical 
causes, such as tonsillectomy and middle ear surgery, as well as psychogenic causes should be added (1-3).

It would be interesting if there was a decrease in body-mass-index within the last year or if it was stable. It would also be interesting if there were any changes in medication since the accident and why and how often the patient took naproxen, as it may cause stomatitis and glossitis.

It would be interesting if the patient reported complaints of flavor perception.

With regard to the performance of the three-drop taste threshold, it should be mentioned that the usual way of testing starts with the lowest concentration in order to avoid adaptation. Moreover, this test measures gustatory function of the whole mouth similar to the swish and spit test.

The authors used a two-alternative forced-choice taste test and concluded that every deviation from a 50 percent result in ageusic patients might be suspicious of malingering. However, it has to be stated that this is not always the case and that simple and quick tests cannot guarantee the suggested confidence in detection of malingering. In some circumstances more elaborate tests (e.g., event-related potentials) are needed.

In summary, we would like to thank the authors for this interesting case report, as further research in the field of rare causes of taste disorders are necessary.

\section{References}

1. Mueller CA, Khatib S, Landis BN, Temmel AF, et al.: Gustatory function after tonsillectomy.Arch Otolaryngol Head Neck Surg. 2007; 133 (7): 668-71 PubMed Abstract | Publisher Full Text

2. Mueller CA, Khatib S, Naka A, Temmel AF, et al.: Clinical assessment of gustatory function before and after middle ear surgery: a prospective study with a two-year follow-up period.Ann Otol Rhinol Laryngol. 2008; 117 (10): 769-73 PubMed Abstract | Publisher Full Text

3. Kazour F, Richa S, Desmidt T, Lemaire M, et al.: Olfactory and gustatory functions in bipolar disorders: A systematic review.Neurosci Biobehav Rev. 2017; 80: 69-79 PubMed Abstract | Publisher Full Text

Is the background of the case's history and progression described in sufficient detail? Yes

Are enough details provided of any physical examination and diagnostic tests, treatment given and outcomes?

Yes

Is sufficient discussion included of the importance of the findings and their relevance to future understanding of disease processes, diagnosis or treatment? Yes

Is the case presented with sufficient detail to be useful for other practitioners? Yes

Competing Interests: No competing interests were disclosed. 


\section{We confirm that we have read this submission and believe that we have an appropriate level of expertise to confirm that it is of an acceptable scientific standard, however we have significant reservations, as outlined above.}

Reviewer Report 19 April 2017

https://doi.org/10.5256/f1000research.12128.r21955

(C) 2017 Marroni C et al. This is an open access peer review report distributed under the terms of the Creative Commons Attribution License, which permits unrestricted use, distribution, and reproduction in any medium, provided the original work is properly cited.

\section{Claudio Augusto Marroni}

Post Graduate Program in Medicine: Hepatology, Federal University of Health Sciences of Porto Alegre, Porto Alegre, Brazil

\section{Sabrina A. Fernandes}

Post Graduate Program in Medicine: Hepatology, Federal University of Health Sciences of Porto Alegre, Porto Alegre, Brazil

Firstly, we would like to congratulate the authors for the choice of the case, an interesting subject of great scientific relevance. The structuring of the case report is well documented and with a helpful review of the scientific literature on the hypotheses of the patient's clinical condition against hypogeusia.

We have developed a line of argument on the subject, raised some issues that we consider important to contribute to the understanding of the case.

The tongue is a muscular organ located on the floor of the mouth, its root is the posterior part, the apex lies in the anterior extremity and the dorsum is divided by a middle groove in symmetrical halves. It contributes to chewing by placing food between the teeth and plays an important role in deglutition and articulation of speech sounds ${ }^{(1)}$.

The shape of the tongue presents a characteristic appearance due to the presence of small protrusions, called lingual or gustatory papillae, that are distributed in great quantity before the terminal sulcus. The taste buds are small appendages filled with sensory cells. These cells are attached to our brain by nerve fibers ${ }^{(1)}$.

The papillae of the tongue are composed of connective tissue covered by stratified squamous epithelium and, by their appearance, are classified into four types: filiform, fungiform, goblet or circumvalate and foliaceous or foliate ${ }^{(1)}$.

The taste buds are responsible for the palate. There are names for disturbances involving the taste buds. When the sensitivity of the palate is diminished, it is classified by hypogeusia; The altered sensitivity is called dysgeusia and, finally, the ageusia is the absence of palate (2).

Decreased palate may be associated with clinical malnutrition in diabetes mellitus, Cushing's 
disease, systemic arterial hypertension, obesity, adrenalectomy, neoplasias and chronic diseases, drug consumption, radiotherapy and surgical interventions, aging, saliva composition, Smoking and eating habits, mood and feelings of hunger or satiety (2).

The reduction of the foleal papillae occurs significantly with age and the location of the dysgeusia of the evaluated patient is in the same location of these papillae.

Dysgeusia is directly related to the characteristic of the taste buds. The taste buds present four types of cells, type I, II, III and IV, which are responsible for the transduction of the taste signal and, according to the disease that the patient may present, these cells may have a disruption.

\section{Type I Cells}

Type I cells are the most abundant in the mammalian gustatory system (3) and are responsible for the hydrolysis of a portion of extracellular ATP which is a neurotransmitter of the palate as well as glutamate. Type I cells appear to be involved in the synaptic transmission that encloses and restricts signal propagation by the transmitter, performed in the central nervous system by the glial cells ${ }^{(4)}$.

In addition, type I cells have a homeostasis power through $\mathrm{K}^{+}$channels ${ }^{(2)}$. During prolonged courses of action potentials stimulated by intense taste stimulation, type I cells release $\mathrm{K}^{+}$which accumulates in the interstitial limited spaces of the taste bud and decrease the excitability of the other cell types. Thus, type I cells appear to function as glial cells in taste buds (3).

Type I cells may have ionic currents implicated in taste signal transduction(4). Although it is the most abundant type of cell in the palate, very little is known about type I cells.

\section{Type II Cells}

Type II cells function within the taste buds and are incorporated into the plasma membrane of these cells, where receptors bind to bitter, sweet, or umami compounds. These flavor receptors are coupled to the GPCR-G protein (second messenger) of receptors with seven transmembrane domains ${ }^{(4)}$.

Type II cells express $\mathrm{Na}^{+}$and $\mathrm{K}^{+}$ion channels essential for the production of action potentials and structural subunits of "key" readers for ATP secretion. Any type II cell can bind to the GPCR-specific $\mathrm{G}$ protein family to identify taste, such as sweet or bitter, but not both (4).

In recognition of their role as the main detectors of these palate classes, type II cells were renamed "receptor" cells. Type II cells do not appear to be directly stimulated by acid or salty (4).

The recipient cells do not form an ultrastructure capable of performing synapses for certain flavors. Presumably, the nerve fibers of these cells have different forms of afferent synaptic connections. Signals transmitted from afferent receptor sensory cells or other cells within the gustatory papilla should be made by unconventional mechanisms, i.e. without the involvement of synaptic vesicles ${ }^{(5)}$. 


\section{Type III Cells}

The consensus is that type III cells express proteins associated with synapses and that form synaptic junctions with nerve terminals ${ }^{(5)}$. These cells express a number of genes, surface cell adhesion molecules, enzymes for the synthesis of at least two neurotransmitters and the $\mathrm{Ca}^{++}$ion channels typically associated with the release of neurotransmitters (5).

Type III cells, which express synaptic proteins and rapid $\mathrm{Ca}^{++}$-dependent depolarization, are characterized as "presynaptic." Type III cells, because they are signal receptors (presynaptic cells), are also excitable and express a complement of $\mathrm{Na}^{+}$channels and $\mathrm{K}^{+}$channels to support action potentials ${ }^{(5)}$.

Innervation where the synapse of type III cells, which appears to be by afferent connections, is not known. In addition to the above-mentioned neuronal properties, presynaptic cells also respond directly to stimuli to bitter taste and carbonate solutions and are presumably the cells responsible for signaling such sensations ${ }^{(5)}$.

\section{Type IV Cells}

The type IV cell is characterized by having a spherical or ovoid shape that does not extend to taste processes and is likely to be undifferentiated cell of the palate or immature ${ }^{(6)}$.

Some researchers identify type IV cells as repositories in the process of apoptosis of the others. This cell class would be the progenitor, guaranteeing the homeostasis of the other groups. Its real functions and characterization as basal cell are to be clarified $(7,8)$.

In the presented report we can raise the hypothesis that a deformity occurred in the structure of these cells of rapid prolifeferation, significantly compromising the signal transmission.

We know that zinc is responsible for the formation of alpha-gustine, the protein responsible for taste, an alternative could have been offered a treatment of chelated zinc for three months, waiting for the recovery of the papillae.

Once again, we congratulate the work and note the importance of improving the early identification of palate dysfunction in the clinical area, since numerous diseases present this clinical picture frequently and end up leading to other comorbidities.

\section{References}

1. Murray RG: The ultrastructure of taste buds.In: Friedmann I. The Ultrastructure of sensory organs. North Holland: Amsterdam. 1973. 1-81

2. Davidson HI, Pattison RM, Richardson RA: Clinical undernutrition states and their influence on taste.Proc Nutr Soc. 1998; 57 (4): 633-8 PubMed Abstract

3. Jung HS, Akita K, Kim JY: Spacing patterns on tongue surface-gustatory papilla.Int J Dev Biol. 2004; 48 (2-3): 157-61 PubMed Abstract | Publisher Full Text

4. Finger TE, Danilova V, Barrows J, Bartel DL, et al.: ATP signaling is crucial for communication from taste buds to gustatory nerves.Science. 2005; 310 (5753): 1495-9 PubMed Abstract | Publisher 
Full Text

5. Vandenbeuch A, Kinnamon SC: Why do taste cells generate action potentials?. J Biol. 2009; 8 (4):

42 PubMed Abstract | Publisher Full Text

6. Simon SA, de Araujo IE, Gutierrez R, Nicolelis MA: The neural mechanisms of gustation: a distributed processing code.Nat Rev Neurosci. 2006; 7 (11): 890-901 PubMed Abstract | Publisher Full Text

7. Gao N, Lu M, Echeverri F, Laita B, et al.: Voltage-gated sodium channels in taste bud cells.BMC Neurosci. 2009; 10: 20 PubMed Abstract | Publisher Full Text

8. Chaudhari N, Roper SD: The cell biology of taste.J Cell Biol. 2010; 190 (3): 285-96 PubMed Abstract | Publisher Full Text

Is the background of the case's history and progression described in sufficient detail? Yes

Are enough details provided of any physical examination and diagnostic tests, treatment given and outcomes?

Yes

Is sufficient discussion included of the importance of the findings and their relevance to future understanding of disease processes, diagnosis or treatment?

Yes

Is the case presented with sufficient detail to be useful for other practitioners? Yes

Competing Interests: No competing interests were disclosed.

We confirm that we have read this submission and believe that we have an appropriate level of expertise to confirm that it is of an acceptable scientific standard. 
The benefits of publishing with F1000Research:

- Your article is published within days, with no editorial bias

- You can publish traditional articles, null/negative results, case reports, data notes and more

- The peer review process is transparent and collaborative

- Your article is indexed in PubMed after passing peer review

- Dedicated customer support at every stage

For pre-submission enquiries, contact research@f1000.com 